\title{
Modelling Water Quality Improvements in a South Korean Inter-Basin Water Transfer System
}

\author{
Hye Won Lee ${ }^{1}\left(\mathbb{D}\right.$, Bo-Min Yeom ${ }^{2}$ and Jung Hyun Choi ${ }^{1,2, *(1)}$ \\ 1 Center for Climate/Environment Change Prediction Research, Ewha Womans University, 52, \\ Ewhayeodae-gil, Seodaemun-gu, Seoul 03760, Korea; hwon@ewha.ac.kr \\ 2 Department of Environmental Science and Engineering, Ewha Womans University, 52, Ewhayeodae-gil, \\ Seodaemun-gu, Seoul 03760, Korea; yoem21@hanmail.net \\ * Correspondence: jchoi@ewha.ac.kr; Tel.: +82-2-3277-6686
}

Received: 21 September 2020; Accepted: 12 November 2020; Published: 13 November 2020

\begin{abstract}
In this study, we investigated the feasibility of using constructed wetlands for non-point source pollution reduction. The effect of constructed wetlands in reducing suspended solids (SS) was analyzed using an integrated modeling system of watershed model (HSPF), reservoir model (CE-QUAL-W2), and stream model (EFDC) to investigate the behavior and accumulation of the pollution sources based on 2017 water quality data. The constructed wetlands significantly reduced the SS concentration by approximately 30\%, and the other in-lake management practices (e.g., artificial floating islands and sedimentation basins) contributed an additional decrease of approximately $7 \%$. Selective withdrawal decreased in the average SS concentration in the influents by $\sim 10 \%$; however, the effluents passing through the constructed wetlands showed only a slight difference of $1.9 \%$ in the average SS concentration. In order to meet the water quality standards, it was necessary to combine the constructed wetlands, in-lake water quality management, and selective withdrawal practices. Hence, it was determined that the model proposed herein is useful for estimating the quantitative effects of water quality management practices such as constructed wetlands, which provided practical guidelines for the application of further water quality management policies.
\end{abstract}

Keywords: CE-QUAL-W2; constructed wetlands; Doam Lake watershed; EFDC; HSPF; non-point source pollution control; selective withdrawal

\section{Introduction}

Non-point source pollution such as agricultural and industrial discharge and surface runoff are regarded as severe environmental issues impacting water quality in aquatic ecosystems [1]. The loss of soil due to surface runoff, as well as the pollution in the runoff, seepage, and percolation resulting from land management activities has been a major reason for water quality deterioration [2]. Since soil erosion is dependent on soil properties, ground slope, vegetation, and rainfall amount and intensity, land-use patterns and characteristics of precipitation can increase soil erosion [3].

Turbidity alone is a major indicator of water pollution and is also used as a surrogate variable for suspended solids concentrations [4]. The scattering particles include suspended silt and clay grains, algae and other plankton, microbes, organic matter, and other fine, insoluble particles. Suspended solids are the primary indicator of pollution [5]. High turbidity and associated suspended solids concentration levels result in various problems such as light suppression effects, contribution to biochemical oxygen demand (BOD) levels, and ecological impacts on macroinvertebrate fauna and fish $[4,6,7]$. This problem disrupts the use of water resources and degrades the landscape values of the water system, destroying the aquatic ecosystem. 
In South Korea, highland agriculture, which is concentrated in the northeastern mountainous areas, is a major cause of soil erosion due to high altitudes and inclined areas. The Korean Peninsula, as a monsoon area, has frequent precipitation events, receiving more than two-thirds of its annual precipitation from July to September. This intense rainfall overlaps with the harvest period in highland agriculture when there is bare soil, which increases sediment delivery loads into the water bodies. Therefore, the bare furrows of high and steep terrain have been considered hotspots of non-point source pollution due to soil erosion during the senescence period [8,9]. Furthermore, highland cultivation tends to use excess organic and chemical fertilizers to yield high profits. The pesticides and fertilizers, which are introduced into the water system during the summer rainfall, cause turbidity and eutrophication problems.

The Doam Reservoir, which is located in the northeastern mountainous areas in South Korea, has severe issues with the continuous turbid water phenomenon caused by highland-originating non-point sources pollution and has inter-basin water transfer from the Doam Dam to Kangnung Namdae Stream for hydropower generation. A severe turbidity problem in the upper area of the inter-basin water transfer system has affected the water quality of the associated downstream area. Due to this, dam operation for electricity generation was suspended in 2001, and Doam Lake watershed has been managed to reduce non-point source pollution since 2007. A muddy water reduction project, including a bypass channel, slope protection methods, and a settlement site, was applied to the system as a watershed management practice, which was carried out with an emphasis on the installation of a large-scale sedimentation site that is expected to reduce the sediment load in the long term. Despite implementation of the project, the suspended solid (SS) concentration in the Doam Reservoir measured in $2014(\sim 9.0 \mathrm{mg} / \mathrm{L})$ did not meet the target water quality levels $(5 \mathrm{mg} / \mathrm{L})$. Therefore, in addition to the currently implemented watershed management practices, it is necessary to devise additional water management practices to regenerate the Doam Dam.

Constructed wetlands are recommended to control the problematic turbid water in the downstream water body. These structures are effective at removing pollutants, geologically flexible and appropriate for sites close to wastewater sources; they are often used as the final treatment stage in large municipal systems $[10,11]$. Additionally, the operation requires neither external power for aeration and mixing nor chemical agents and artificial carriers [12]. The constructed wetland includes major mechanisms for removing pollutant sources: (1) physical sedimentation, filtration, and adsorption for removing suspended solids and some pathogens [13]; (2) microbial mechanisms on plant biomass for nitrogen removal by denitrification, decomposition of organic matter, and removal of pathogens [14]; (3) plant absorption of nitrogen, phosphate, and heavy metals through biological removal [11,15]. We also considered in-lake management practices, such as vegetated artificial floating islands, sedimentation basins, and selective withdrawal for temporary management of the high sediment inflow; however, the actual reduction efficiency on suspended solids that would result from the implementation of water quality management practices is difficult to predict. In order to determine whether they will meet water quality standards, a modeling process is needed to predict the quantitative efficiency of the practices in sediment reduction.

This study attempts to investigate the quantitative effects of non-point source pollution reduction management practices on water quality through modeling. The effect of constructed wetlands on non-point source pollution removal is analyzed by an integrated modeling system of watershed model (HSPF), reservoir model (CE-QUAL-W2), and stream model (EFDC) to investigate the behavior and accumulation of pollution sources. By simulating scenarios in which the removal efficiency of constructed wetlands is coupled with other water management practices, we built an optimal modeling tool and aided the watershed managers in making decisions for the application of constructed wetlands in the study area. This study is expected to provide insight into the efficient operation of sediment management policies by predicting the results of applied management practices. 


\section{Materials and Methods}

\subsection{Study Area}

This study was performed at the Doam Lake and Kangnung Namdae Stream watersheds, which are located in the eastern region of South Korea. The Doam Lake watershed has an area of $151.2 \mathrm{~km}^{2}$, which consists of $77.7 \%$ forest area. Recently, the forest area was under construction to prepare for the 2018 Winter Olympic Games in Pyeongchang, increasing the construction area to approximately five times that of 2009. Furthermore, highland agriculture, which can be a major source of sediment runoff, occupies approximately $11 \%$ of the total watershed. The hydrologic characteristics of the watershed have been significantly affected by the East Asian summer monsoon climate, which is responsible for over $50 \%$ of the annual precipitation in July and August. The annual average temperature and precipitation of the watershed were $7.40{ }^{\circ} \mathrm{C}$ and $1128.2 \mathrm{~mm}$, respectively, from 2008 to 2017 (Korea Meteorological Administration, KMA, Seoul, Korea) [16]. The Doam Dam, which was constructed in 1990 by blocking the Songcheon for power generation, conveys water from Doam Lake to the Kangnung Hydroelectric Power Plant through a $15.6 \mathrm{~km}$ underground channel; however, its operation has been suspended since 2001 due to water quality deterioration in Kangnung Namdae Stream, leading to the release of the water naturally to the downstream area of Songcheon.

Kangnung Namdae Stream watershed has an area of $256.11 \mathrm{~km}^{2}$, which consists of $75.2 \%$ forest land and $17.1 \%$ agricultural area. The ten-year (2008-2017) mean annual temperature was $13.5^{\circ} \mathrm{C}$ and the precipitation was $1245.8 \mathrm{~mm}$, with approximately one-third of the amount occurring from July to August. Kangnung Namdae Stream is located between the mountainous area and the shore side of the East Sea. The stream combines two incoming tributaries at the Obong Dam and releases some of the water to mix with the discharged water of the Kangnung Hydroelectric Power Plant. As the Obong Dam serves as a supplier of the water flow to the stream, it is important to release the proper amount of water to maintain the function and state of the stream under normal conditions. The Obong Dam, however, has supplied a water flow amount below that of the instream flow, with the result that the Kangnung Namdae Stream has suffered severe water pollution [17].

\subsection{Model Selection and Application}

The study area comprised of Doam Lake watershed with Doam Dam and Kangnung Namdae Stream with a steep gradient. To simulate three study area with different characteristics, three different models were selected with respect to the feasibility and performance of models.

Doam Lake watershed has a complex land-use pattern resulting from the increase in urban land cover. Thus, we chose the HSPF model, which is integrally applicable to both rural and urban areas, for simulating the hydrological factors and water quality on the land surfaces and water bodies in the watershed [18-20]. The details of the modeling process were depicted in a previous research paper [17]. Although there are limitations in the quantitative evaluation, as artificial factors are not considered, it can be noted that the model generally simulates the trend of observed data in this study area and is able to simulate the peak concentrations during heavy rainfall in the summer.

Doam Lake, which is an artificial lake formed by the construction of a large dam in a mountainous area, is a dendritic reservoir with a long and relatively narrow shape. Therefore, it is suitable to apply the laterally averaged, two-dimensional hydrodynamic model CE-QUAL-W2 for simulating the hydrodynamic characteristics and water quality of the water body [21-23]. Yeom et al. [16] described the specific methods used in the model, and the calibration results were given therein. The results showed a high degree of coincidence in the simulated and observed SS concentration data. Some water quality fluctuations were not taken into account when the watershed runoff was large, and the error related to the sediment inflow in the summer caused by the Winter Olympics was not considered in the model.

To determine the resumption of the power generation operation, which discharges water from Doam Lake to Kangnung Namdae Stream, the three-dimensional hydrodynamic and water quality 
model EFDC was selected to simulate the water quality change in Kangnung Namdae Stream. A description of the EFDC model can be found in $\mathrm{Wu}$ and $\mathrm{Xu}$ [24]. In order to attain the three-dimensional modeling output using EFDC, curvilinear orthogonal grids were employed to represent the complex geometry of the stream; the model grids are composed of 1000 horizontal layers and one vertical layer. Meteorological data, including air temperature, atmospheric pressure, precipitation, relative humidity, and solar radiation, were obtained from KMA [16].

Calibration (2017) and validation (2018) were performed to validate the EFDC model for water level simulation of DG2 presented in Figure 1. The value for $r^{2}$ (Pearson's correlation coefficient) of surface water level during the calibration period was 0.99 . Pearson's $r$ is a statistic that measures the linear correlation between two variables-X (observed surface water level) and Y (simulated surface water level). The value of 0.99 , being close to 1 , means that the values of the simulated surface water level are well matched with those observed, as illustrated in Figure 2. Figures 3 and 4 show the observed versus simulated daily temperature and SS concentration for calibration (2017) and validation (2018). In this study, the calibration was carried out, and parameters determined by calibration were used for the validation of the model (Table 1). The temperature and SS calibration and validation were calculated using data from three stations (DG1, DG2, and DG3) measured in 2017 and 2018 by the Korea Ministry of Environment (ME) [25]. Performance of the EFDC model was tested by calculating $\mathrm{O} / \mathrm{S}$ and root mean square error (RMSE). The equations for calculating these values are $\mathrm{O} / \mathrm{S}=\frac{\overline{O_{i}}}{\overline{S_{i}}}$, and RMSE $=\sqrt{\frac{\sum_{i=1}^{n}\left(S_{i}-O_{i}\right)^{2}}{n}}$, where $O_{i}$ and $S_{i}$ are the observed and simulated values, respectively, and $n$ is the number of values. The calibration results of the temperature indicate a range of $0.94-1.06{ }^{\circ} \mathrm{C} \mathrm{O} / \mathrm{S}$ and 1.98-2.35 ${ }^{\circ} \mathrm{C}$ RMSE, respectively. The calibration results of the SS concentration indicate a range of 1.08-1.49 mg/L O/S and 0.49-4.23 mg/L RMSE, respectively. Table 2 shows the results for the observed and simulated mean, $\mathrm{O} / \mathrm{S}$, and RMSE. O/S, which indicates the relative error between temperature and SS concentration, is within approximately 10-20\%, excluding the SS concentration at the DG2 point. Values of RMSE were low, indicating that the model simulation matched the observed data well. It is expected that the discrepancy between the model and the actual measurement shown in the calibration and verification of the model did not reflect the pollution from the construction of the Olympic infrastructure.

Table 1. Main coefficient for calibration and validation parameters used in the EFDC model.

\begin{tabular}{crcc}
\hline Coefficient & Definition & Unit & Value Used \\
\hline $\mathrm{Z}_{0}$ & Bottom roughness height & $\mathrm{m}$ & $0.005-0.02$ \\
\hline $\mathrm{AHO}$ & Constant horizontal momentum and mass diffusivity & $\mathrm{m}^{2} / \mathrm{s}$ & 1.0 \\
\hline $\mathrm{AHD}$ & Dimensionless horizontal momentum diffusivity & $\mathrm{m}^{2} / \mathrm{s}$ & 0.15 \\
\hline $\mathrm{AVO}$ & Background kinematic eddy viscosity & $\mathrm{m}^{2} / \mathrm{s}$ & $1 \times 10^{-6}$ \\
\hline $\mathrm{ABO}$ & Background molecular diffusivity & $\mathrm{m}^{2} / \mathrm{s}$ & $2 \times 10^{-9}$ \\
\hline $\mathrm{DABEDT}$ & Thickness of active bed temperature layer & $\mathrm{m}$ & 5 \\
\hline TBEDIT & Initial bed temperature & ${ }^{\circ} \mathrm{C}$ & 12 \\
\hline HTBED2 & Heat transport coefficient between bed and bottom water layer & $\mathrm{W} / \mathrm{m}^{2} /{ }^{\circ} \mathrm{C}$ & 0.3 \\
\hline
\end{tabular}


Table 2. Fit of the EFDC model.

\begin{tabular}{|c|c|c|c|c|c|c|}
\hline & Output Variable & Station & Observed Mean & Simulated Mean & $\mathrm{O} / \mathrm{S}$ & RMSE \\
\hline \multirow{6}{*}{ Calibration } & \multirow{3}{*}{ Temperature } & DG1 & 14.8 & 15.7 & 0.94 & 2.35 \\
\hline & & DG2 & 15.8 & 14.8 & 1.06 & 2.24 \\
\hline & & DG3 & 16.2 & 15.6 & 1.04 & 1.98 \\
\hline & \multirow{3}{*}{ Suspended Solids } & DG1 & 1.8 & 1.7 & 1.08 & 0.49 \\
\hline & & DG2 & 3.2 & 2.1 & 1.49 & 4.23 \\
\hline & & DG3 & 4.2 & 3.0 & 1.43 & 3.93 \\
\hline \multirow{6}{*}{ Validation } & \multirow{3}{*}{ Temperature } & DG1 & 13.2 & 13.8 & 0.96 & 3.17 \\
\hline & & DG2 & 12.6 & 10.6 & 1.19 & 4.26 \\
\hline & & DG3 & 13.8 & 11.8 & 1.18 & 2.82 \\
\hline & \multirow{3}{*}{ Suspended Solids } & DG1 & 2.1 & 1.9 & 1.08 & 2.72 \\
\hline & & DG2 & 1.1 & 1.8 & 0.61 & 1.59 \\
\hline & & DG3 & 2.7 & 2.6 & 1.06 & 1.70 \\
\hline
\end{tabular}

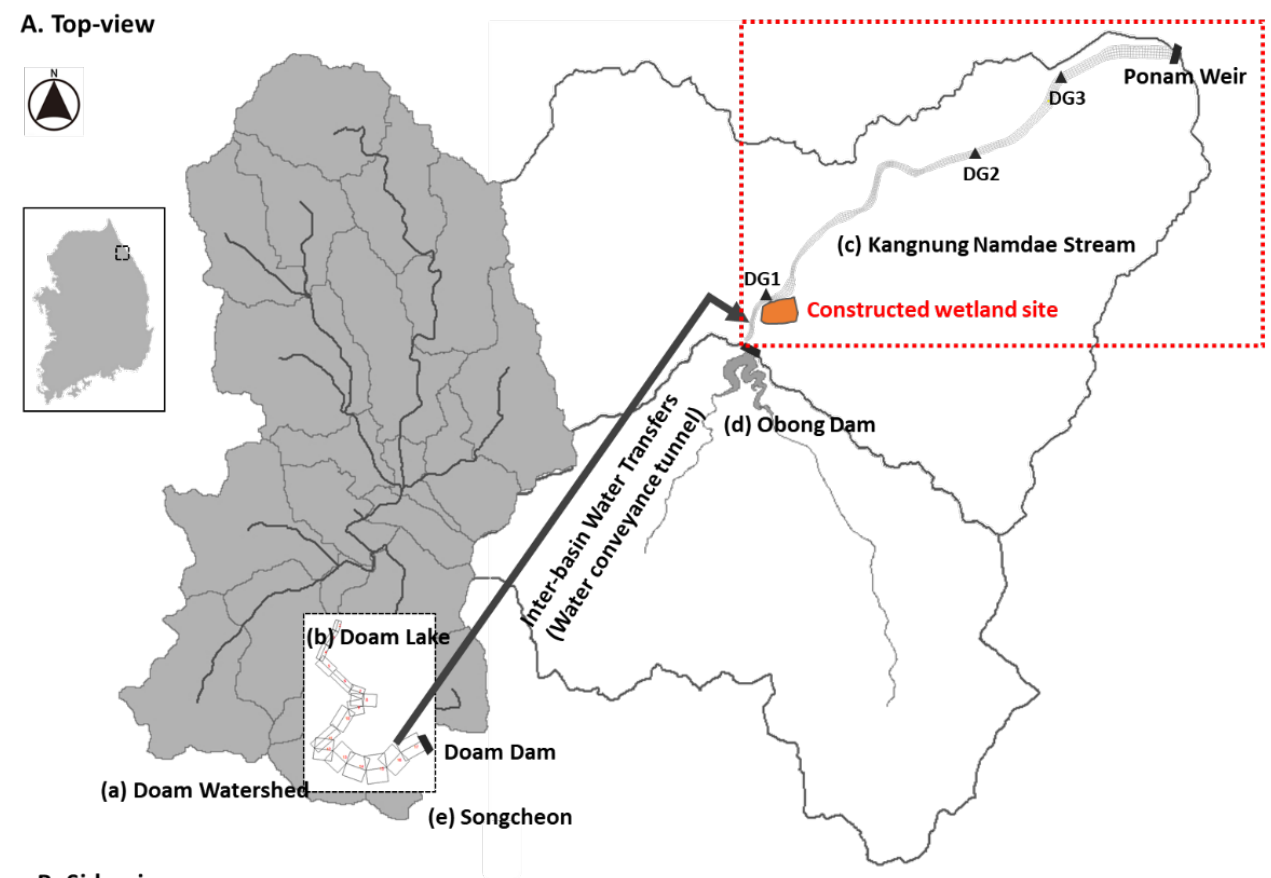

B. Side-view

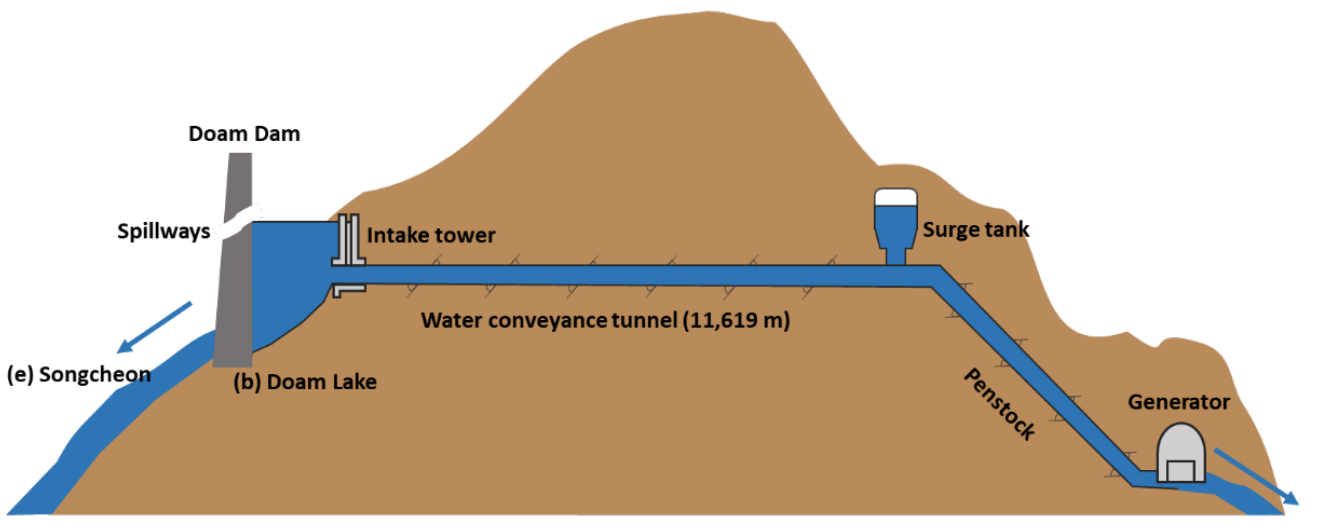

(c) Kangnung Namdae Stream

Figure 1. Thematic geographic information system maps and monitoring sites of the study area. (A) Top-view of study area: (a) the watershed model (HSPF) sub-basin map of the Doam Lake watershed, (b) reservoir model (CE-QUAL-W2) segment definition map of Doam Lake, and (c) stream model (EFDC) grids of Kangnung Namdae Stream (red dotted box). (B) Side-view of study area. 


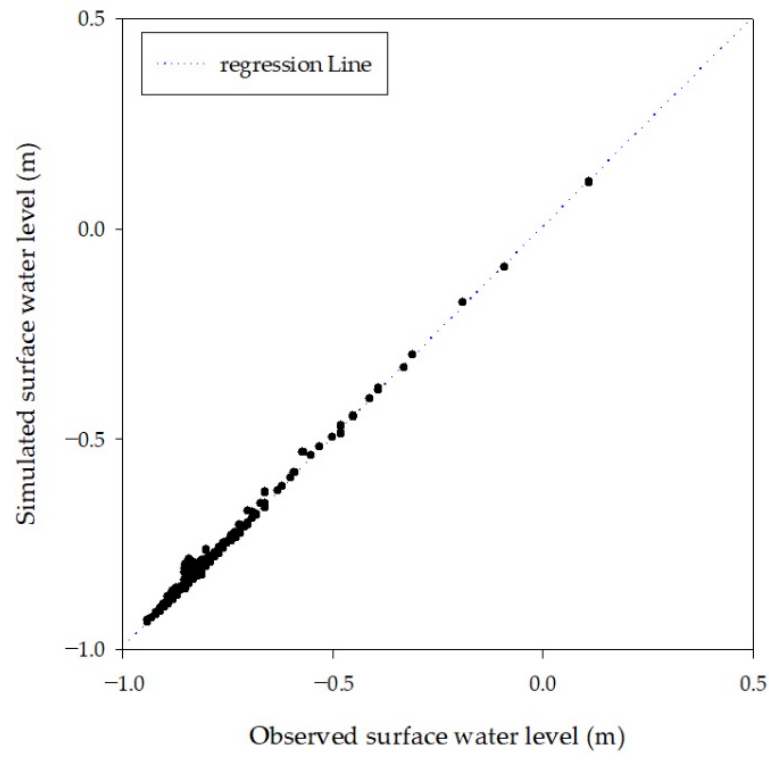

Figure 2. Results of the EFDC model calibration for the surface water level in Kangnung Namdae Stream.
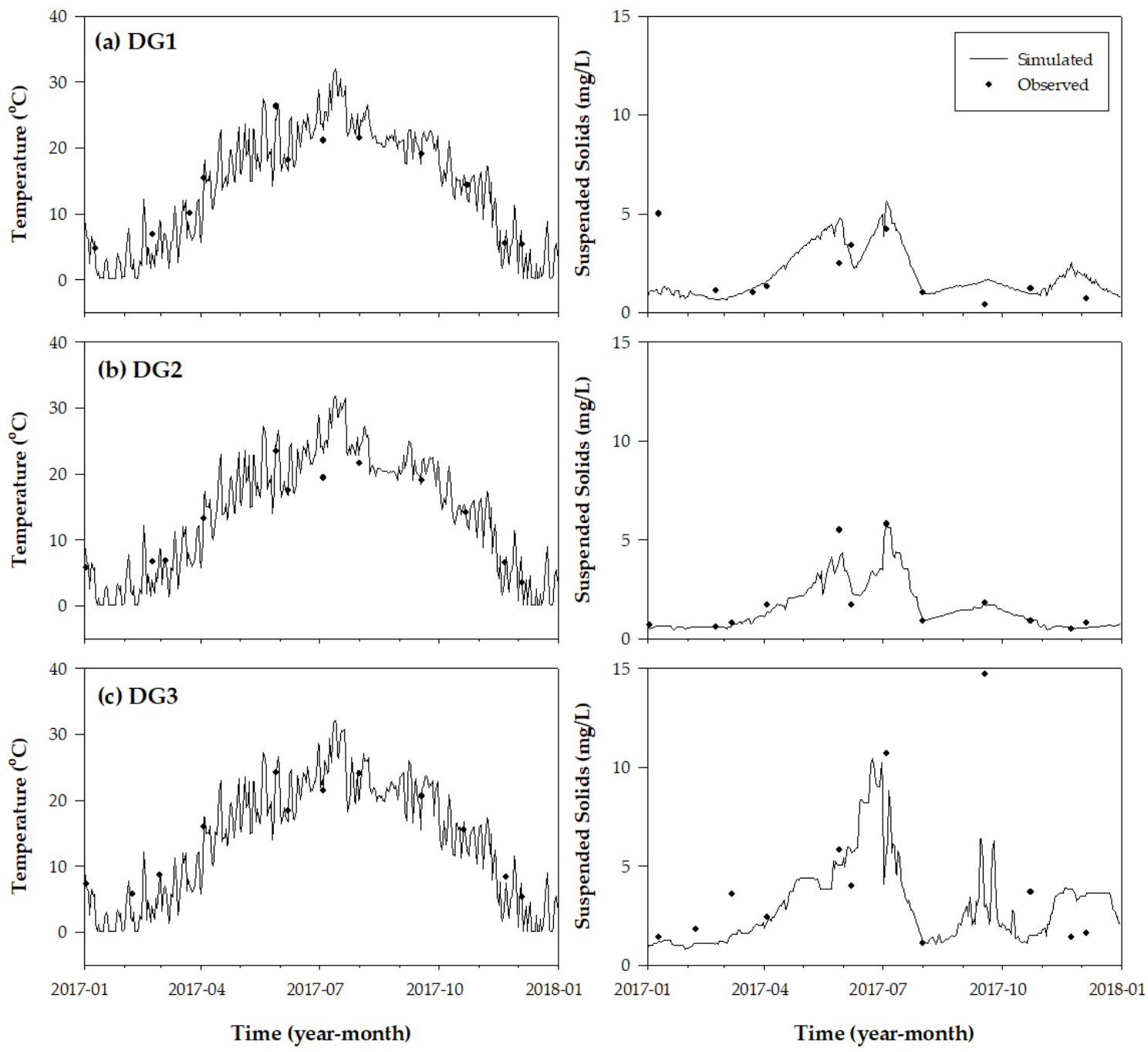

Figure 3. Results of the EFDC model calibration for the temperature and suspended solids (SS) concentration in Kangnung Namdae Stream at (a) DG1, (b) DG2, and (c) DG3. 

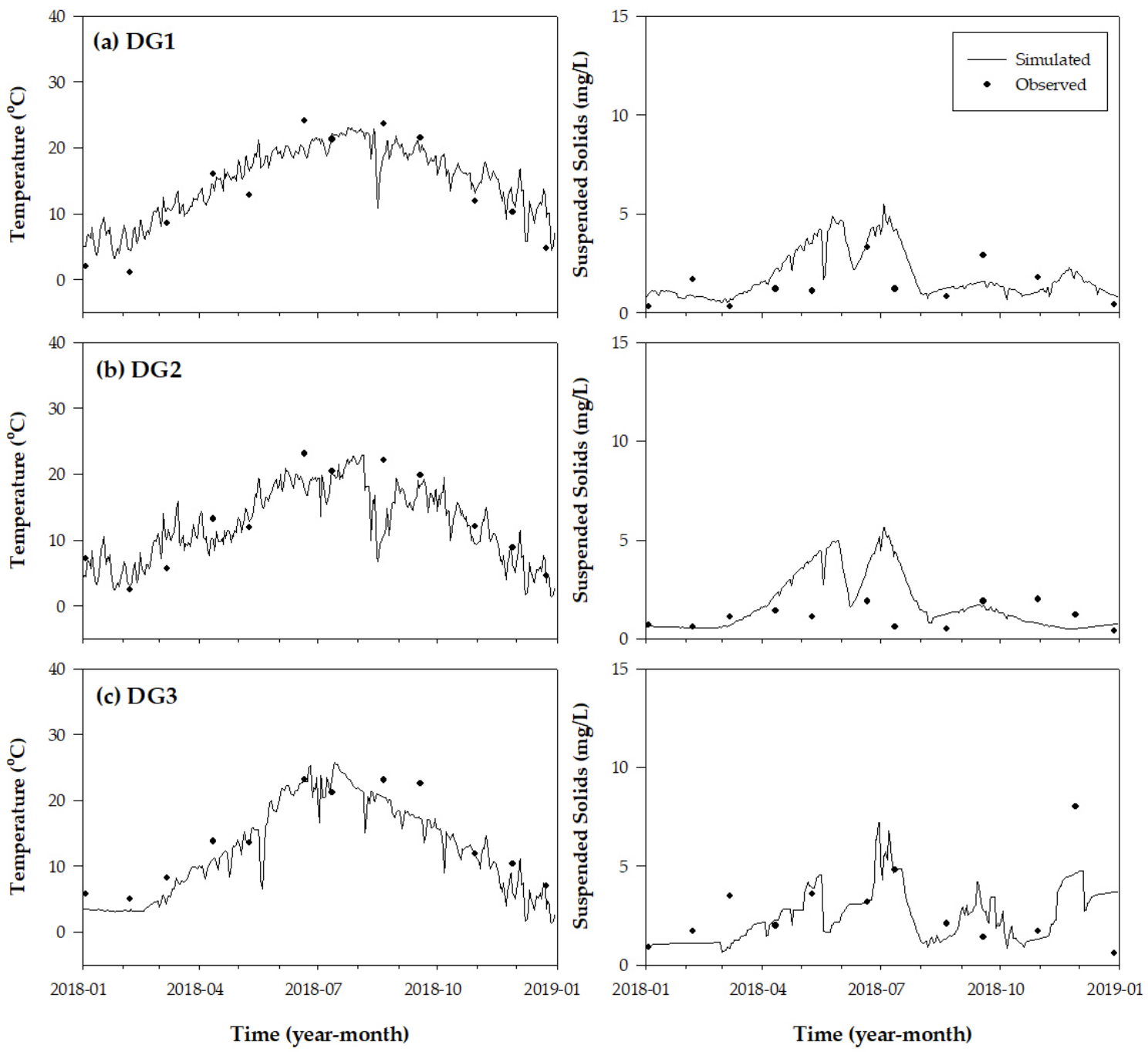

Figure 4. Results of the EFDC model validation for the temperature and SS concentration in Kangnung Namdae Stream at (a) DG1, (b) DG2, and (c) DG3.

\subsection{Experimental Configuration}

In order to investigate the efficiency of the water quality management, especially the constructed wetlands, several scenarios were established (Table 3). The watershed management practices were applied by considering the best management practices (BMP) efficiency in the HSPF model and assuming that the non-point source pollution management practices in the Doam watershed would reduce soil discharge at the same level as that at present for the next 10 years [26]. In-lake management practices include the construction of artificial floating islands and a sedimentation basin, which can be installed in the inlet, interior, and outlet of the lake. Furthermore, selective withdrawal, which adjusts the withdrawal height, is applied to selectively discharge the low turbidity water; it modulates the withdrawal height between EL.673 and $688 \mathrm{~m}$ flexibly with continuous turbidity monitoring. The specific efficiency is suggested in the report of the methodology development of water quality estimation and impact assessment for the Doam Reservoir [27].

In addition to the watershed and in-lake management practices, the constructed wetlands are installed as secondary reduction practices in Kangnung Namdae Stream. The effluent discharge is based on an average of $4.63 \mathrm{~m}^{3} / \mathrm{s}$, which is the same as the discharged water before the suspension of electric power generation. There is no effluent discharge in the periods of low-flow conditions. In the case of directly discharging the effluents to Kangnung Namdae Stream, water can pass through the 
constructed wetlands to reduce SS concentration. The maximum amount of discharged water from the wetlands is set to $4 \mathrm{~m}^{3} / \mathrm{s}$, and the remainder is planned to flow into the stream, assuming that the discharged water from the Doam Reservoir would be directly transferred into the Kangnung Namdae Stream without undergoing any treatment processes. The reduction efficiency of the constructed wetlands is postulated to be approximately $40 \%-60 \%$ of the SS concentration [28].

The flow rate of effluents flowing into the Kangnung Namdae Stream ranges from 0 to $4.256 \mathrm{~m}^{3} / \mathrm{s}$, with an annual average of $1.323 \mathrm{~m}^{3} / \mathrm{s}$. The SS concentration of the input flow is $5.269 \mathrm{mg} / \mathrm{L}$ in the S1 scenario and 5.043-5.256 mg/L in the S2 and S3 scenarios. The S4 and S5 scenarios, in which the withdrawal height is adjusted by selective intake, have identical conditions in the inflow system, corresponding to $4.606 \mathrm{mg} / \mathrm{L}$ turbidity.

Table 3. Experimental configuration.

\begin{tabular}{|c|c|c|c|c|}
\hline Scenario & $\begin{array}{c}\text { In-Lake } \\
\text { Management }\end{array}$ & $\begin{array}{c}\text { River } \\
\text { Management }\end{array}$ & $\begin{array}{l}\text { Withdrawal } \\
\text { (EL. m) }\end{array}$ & Details \\
\hline S0 & - & - & - & $\begin{array}{l}\text { No discharge to Kangnung } \\
\text { Namdae Stream }\end{array}$ \\
\hline S1 & - & - & Fixed (673) & Resumption of Doam Dam operation \\
\hline S2 & - & $\mathrm{O}$ & Fixed (673) & $\begin{array}{l}\text { Application of constructed wetlands } \\
\text { in Kangnung Namdae Stream }\end{array}$ \\
\hline S3 & $\mathrm{O}$ & $\mathrm{O}$ & Fixed (673) & $\begin{array}{l}\text { Application of in-lake management in } \\
\text { Doam Lake and constructed wetlands } \\
\text { in Kangnung Namdae Stream }\end{array}$ \\
\hline S4 & $\mathrm{O}$ & $\mathrm{O}$ & Selective $(673+688)$ & $\begin{array}{c}\text { Application of all management } \\
\text { practices and selective withdrawal }\end{array}$ \\
\hline S5 & $\mathrm{O}$ & - & Selective $(673+688)$ & $\begin{array}{l}\text { Application of in-lake management in } \\
\text { Doam Lake and selective withdrawal }\end{array}$ \\
\hline
\end{tabular}

\section{Results and Discussion}

\subsection{Characteristic Changes of Kangnung Namdae Stream after Resumption of Power Generation}

Figure 5 shows the temperature and SS concentration of Kangnung Namdae Stream in scenarios in which the power generation is not operational (S0) and after the power generation is restarted (S1). The S1 scenario supposes a situation in which the effluent is discharged at EL. $673 \mathrm{~m}$ through inter-basin water transfers from Doam Lake to Kangnung Namdae Stream. Water temperatures measured after power generation resumption were predicted to be lower than the original water temperature due to the discharge from the middle layer of Doam Lake in the summer season (July, August, and September). At the DG1 site, the temperature difference between the S0 and S1 scenarios varied from 0.2 to $13.6{ }^{\circ} \mathrm{C}$, with an average of $6.2^{\circ} \mathrm{C}$ owing to the direct effect of the discharged effluents without the selective withdrawal control. The DG2 and DG3 sites differed in the range of $0.1-8.3^{\circ} \mathrm{C}$ and $-0.3-6.6^{\circ} \mathrm{C}$, and the means were $3.7^{\circ} \mathrm{C}$ and $3.1^{\circ} \mathrm{C}$, respectively. It is expected that the effluents flowing through a relatively shallow depth of the river diminish the water temperature difference by the discharge, thereby stabilizing the air temperature and heat balance. These results imply that low-temperature effluents may adversely affect the ecosystem. Therefore, a retention pond such as a wetland is necessary to stabilize the water temperature.

The SS concentration at the DG1 site increased from an average of 1.6 to $1.8 \mathrm{mg} / \mathrm{L}$ after the effluent discharge, and the maximum concentration greatly increased from 5.8 to $9.4 \mathrm{mg} / \mathrm{L}$ during the summer time. On the other hand, at the DG3 site, which is located downstream, the average SS concentration decreased from 3.0 to $2.1 \mathrm{mg} / \mathrm{L}$ as the effluent discharge resumed, and the maximum concentration decreased from 10.4 to $8.7 \mathrm{mg} / \mathrm{L}$. Downstream of Kangnung Namdae Stream, there is a weir named Ponam that prevents the backflow of seawater and maintains the river level; it disturbed the stream 
flow smoothly before the discharge of the power generation effluents. Therefore, it had high values of SS concentrations, as the soil flowing down from the Kangnung Namdae Stream basin in the summer rainfall could not be discharged to the sea. It is predicted that the increase in flow rate due to the effluent discharge helped to decrease the downstream SS concentration.
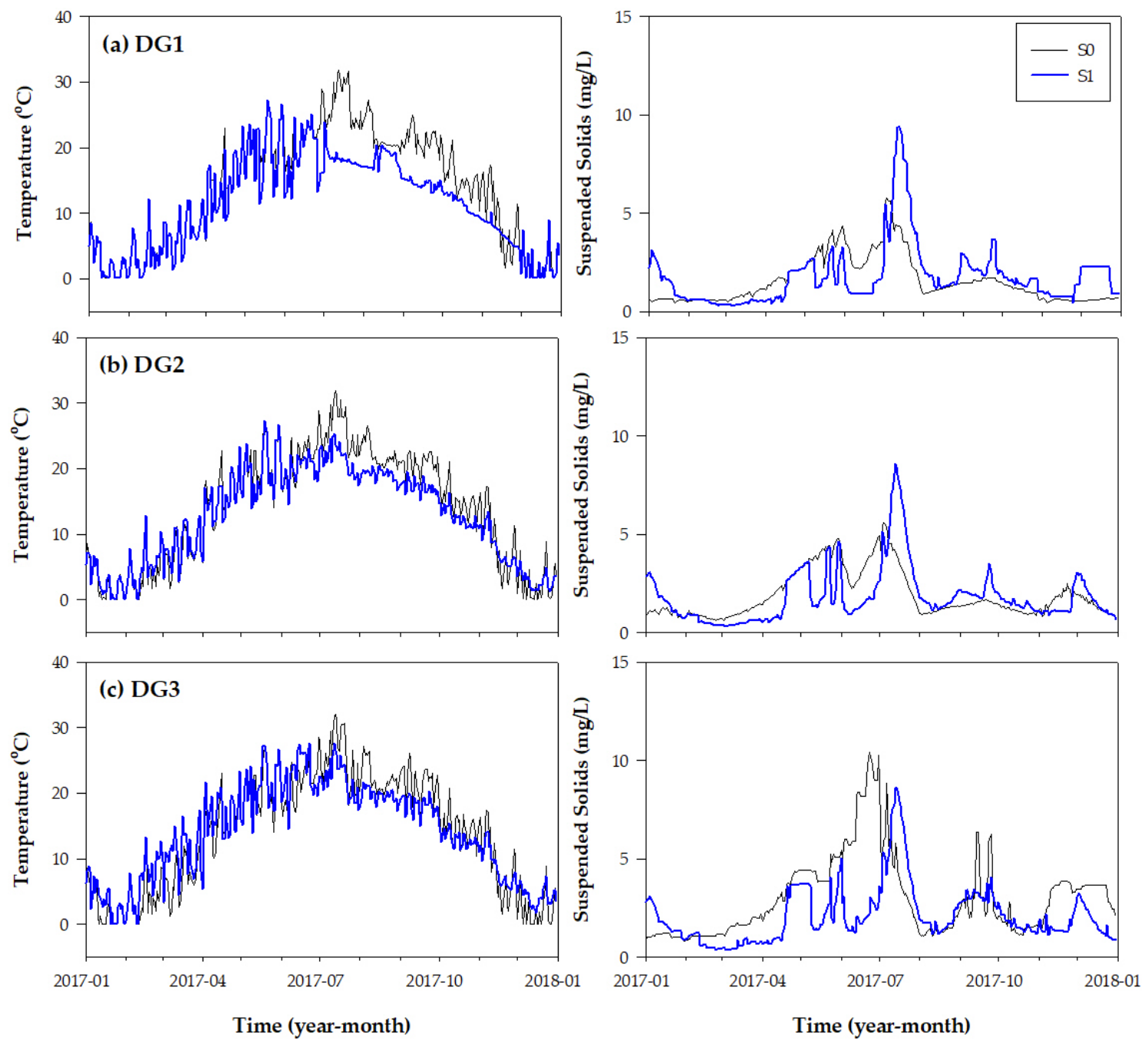

Figure 5. Comparison of the temperature and SS concentration in Kangnung Namdae Stream before and after the discharge of power generation effluents at (a) DG1, (b) DG2, and (c) DG3.

3.2. Analysis of the Simulated Temperature and SS Concentration in Kangnung Namdae Stream under the Application of Water Quality Management Practices

Figure 6 presents the temperature and SS concentration under three different scenarios, including artificial floating islands, a sedimentation basin for in-lake management practices, and constructed wetlands as river management practices. The S2 scenario does not include in-lake management practices but includes constructed wetlands in the upper side of the stream, statically taking water at EL. $673 \mathrm{~m}$. The S3 scenario was the same as the S2 scenario, except it had added artificial floating islands and a sedimentation basin. Accordingly, the results of the S2 and S3 scenarios can be compared to investigate the effects of the in-lake management practices such as artificial floating islands and sedimentation basins.

The results of the temperatures at DG1, DG2, and DG3 in Figure 5 suggest that the constructed wetlands in Kangnung Namdae Stream play a role in the stable water temperature of the stream during summer. At the DG1 site, the average water temperature for the S1 scenario was $11.5{ }^{\circ} \mathrm{C}$, while the 
water temperatures for S2 and S3 were are $13.6{ }^{\circ} \mathrm{C}$ and $13.5^{\circ} \mathrm{C}$, respectively, similar to the average temperature of $13.9^{\circ} \mathrm{C}$ for the $\mathrm{S} 0$ scenario, which occurred before the discharge of power generation effluents. The temperature of the DG2 site was also estimated to be $13.9^{\circ} \mathrm{C}$ for $\mathrm{S} 2$ and $13.7^{\circ} \mathrm{C}$ for S3, which is approximately $1{ }^{\circ} \mathrm{C}$ higher than the average of $12.8^{\circ} \mathrm{C}$ for the $\mathrm{S} 1$ scenario. As a result, it is predicted that the constructed wetlands would have a positive effect on the changes in the downstream water temperature by temporary storage and discharge of low-temperature effluents from the lower layer of EL. $673 \mathrm{~m}$.
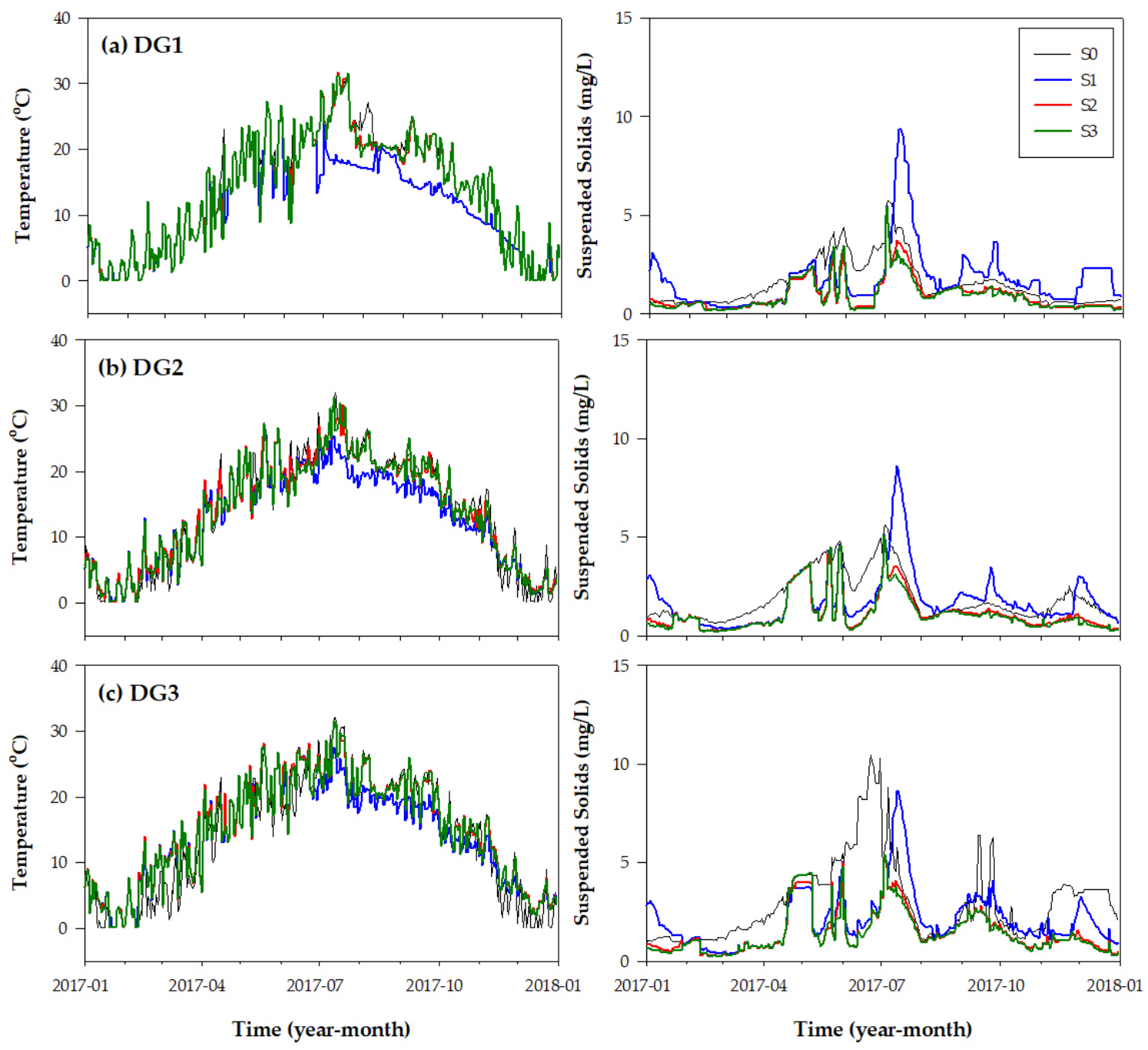

Figure 6. Comparison of the temperature and SS concentration under the in-lake management practices in Doam Lake and the installation of constructed wetlands in Kangnung Namdae Stream at (a) DG1, (b) DG2, and (c) DG3.

From the simulation results of the three sites, it can be seen that the installation of the constructed wetlands in Kangnung Namdae Stream led to a dramatic decrease in the SS concentration in summer. At the DG2 site, the SS concentration had a 36.5\% average decrease in the S2 scenario compared to the S1 scenario. In particular, the SS concentration decreased approximately $45 \%$ in July, September, and October. For the S3 scenario, which examines the impact of the additional installation of artificial floating islands and a sedimentation basin in the lake, the average SS concentration diminished approximately $6.9 \%$ more than the S2 scenario did, and it decreased by approximately $10 \%$ in July, September, and October. Based on these results, it can be determined that the artificial floating islands and sedimentation basin in Doam Lake decreased the SS concentration by approximately 7\%, 
and the constructed wetlands in the Kangnung Namdae Stream decrease the SS concentration by of approximately $30 \%$ per year.

Analysis of the SS concentration changes was conducted for different withdrawal heights. Previous research [17] showed that there was an improvement in the SS concentration when the withdrawal height (EL. $673 \mathrm{~m}$ ) was adjusted to EL. $688 \mathrm{~m}$ after heavy rainfall by preventing sediment inflow. Therefore, we compared the S3 with the S4 scenario to investigate the effects of selective withdrawal. The S3 and S4 scenario results were compared by discharging the water at EL. $673 \mathrm{~m}$ throughout the year (S3) and discharging it at EL. $688 \mathrm{~m}$ at specific periods through monitoring during the summer (S4). In the S3 scenario, the mean SS value of influents flowing into Kangnung Namdae Stream was $2.2 \mathrm{mg} / \mathrm{L}$, and the average SS value in the S4 scenario was $2.0 \mathrm{mg} / \mathrm{L}$, which is a $\sim 10 \%$ difference. When comparing the water quality of the effluents passing through the constructed wetlands of the S3 and S4 scenarios, there was a slight difference of $1.9 \%$ in the SS concentrations. The results suggest that the reduction efficiency of the constructed wetlands upstream of Kangnung Namdae Stream has a more positive effect on the water quality of the stream during the summer than selective withdrawal does.

Although the constructed wetlands are more efficient in reducing the SS concentration, the application of the selective withdrawal is essential at specific periods during the summer. This result is consistent with the results of previous research with respect to selective withdrawal in a thermally stratified reservoir $[29,30]$. The selective withdrawal of a thermally stratified reservoir can supply heat and constituents such as nutrients and dissolved oxygen, downstream of the dam in particular during thermal stratification. The numerical model is utilized as a simple and efficient tool to optimize water withdrawal elevation that alleviate the temperature and nutrient pollution downstream of a reservoir. Figure 7 shows the changes in the temperature and SS concentration of the Kangnung Namdae Stream for the constructed wetlands under selective withdrawal. In the S4 and S5 scenarios with the application of selective withdrawal, the reduction of the SS concentration as a result of the constructed wetlands in Kangnung Namdae Stream was analyzed, and a reduction rate of approximately 16.7\% was predicted by comparing the average SS concentrations. In particular, the high SS concentration of the Doam Lake effluents, which last from June to September, was greatly reduced during the use of constructed wetlands.

Figure 8 shows the results of monthly average changes in SS concentrations per each scenario at the DG2 site. Considering the Korean environmental water quality standards of rivers, the water quality of Kangnung Namdae Stream satisfies the standard of SS $25 \mathrm{mg} / \mathrm{L}$ before and after the discharge of power generation effluents throughout the year. Through the application of the environmental water quality standards of lakes (www.me.go.kr), the water quality of Doam Lake exceeds the standard of SS $5 \mathrm{mg} / \mathrm{L}$ for more than 53 days at the DG3 site without the resumption of power generation (S0). In the S1 scenario with the power generation resumption, the threshold is exceeded for more than 19 days at the DG3 site; however, only two days per year are expected to exceed the standard under the application of in-lake management practices, constructed wetlands, and selective withdrawal. At the DG1 and DG2 sites, the water quality was unable to meet the standard for six and five days before effluent discharge but exceeded the standard for 16 and 14 days, respectively, after the discharge was resumed. The sites were expected to meet the water quality standards, except for on one day that had the highest SS concentration when both the DG1 and DG2 sites applied all practices simultaneously-in-lake management practices, constructed wetlands, and selective withdrawal. The best management practice (BMP) for improving the water quality in Kangnung Namdae Stream is the installation of constructed wetlands, which may improve water quality by passing through the supernatant water to the wetlands for storage and sedimentation. The constructed wetlands provided valuable ecosystem services including flood attenuation, nutrient retention, waste assimilation and carbon storage [31-33]. Considering the potential role of wetlands for water management and wastewater treatment [33], it is expected that the stormwater and watershed discharge can be alleviated by the installation of constructed wetlands in Kangnung Namdae Stream. In addition, the installed constructed wetlands can improve flow regulation services under the influence of global climate changes which increase the 
frequency and power of floods [31,32,34]. The installed constructed wetlands in Kangnung Namdae Stream can reduce the frequency and magnitude of floods and decrease runoff and streamflow.

In terms of the instream flow, the effluents of Doam Dam contribute to securing the instream flow of Kangnung Namdae Stream. As the effluent discharge after the resumption of hydropower generation can affect the flow of the receiving water system, we compared the flow of the receiving water system to the instream flow of Kangnung Namdae Stream. Generally, the instream flow of the river is the amount of flow required to maintain the normal function and state of the river system at the main point of the river. This is a standard for evaluating the achievement of protecting the stream system [35]. The instream flow of Kangnung Namdae Stream is $0.92 \mathrm{~m}^{3} / \mathrm{s}$ according to River Basic Plan of Kangnung Namdae Stream; however, it is currently $0.4 \mathrm{~m}^{3} / \mathrm{s}$, which is insufficient to satisfy the instream flow. The inflow of effluent discharge through the reoperation of Doam Dam is expected to contribute to meeting the instream flow of Kangnung Namdae Stream.

From the analysis of scenarios with the application of several water quality management practices, the application of constructed wetlands is more effective than the application of in-lake management practices and selective withdrawal. Overall, our model suggests that the most efficient method is to combine water quality management practices in Doam Lake (in-lake management practices) with installation of the constructed wetlands in Kangnung Namdae Stream to mediate the withdrawal height.
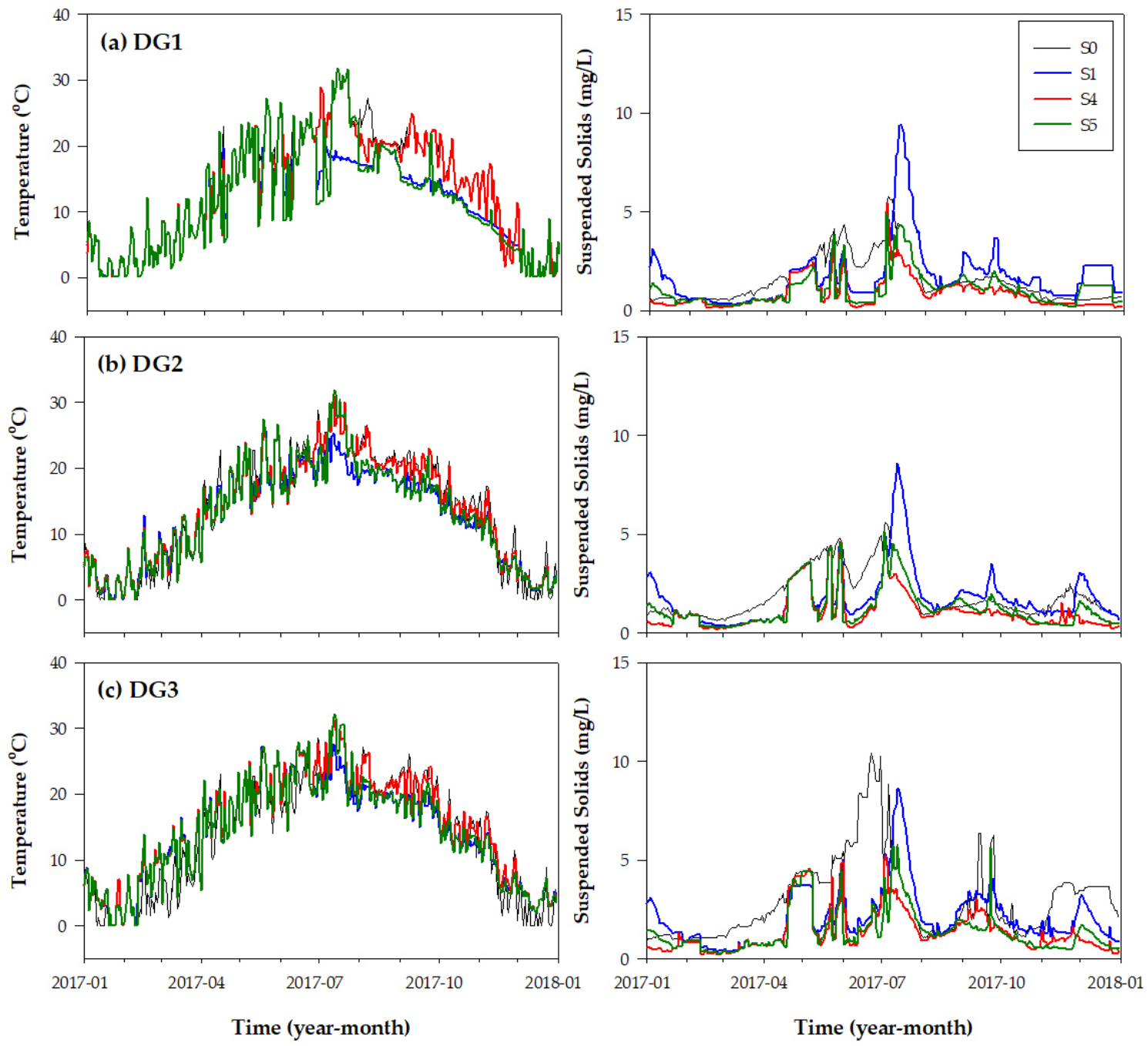

Figure 7. Comparison of the temperature and SS concentration with the selective withdrawal in Doam Lake according to the installation of constructed wetlands in Kangnung Namdae Stream at (a) DG1, (b) DG2, and (c) DG3. 


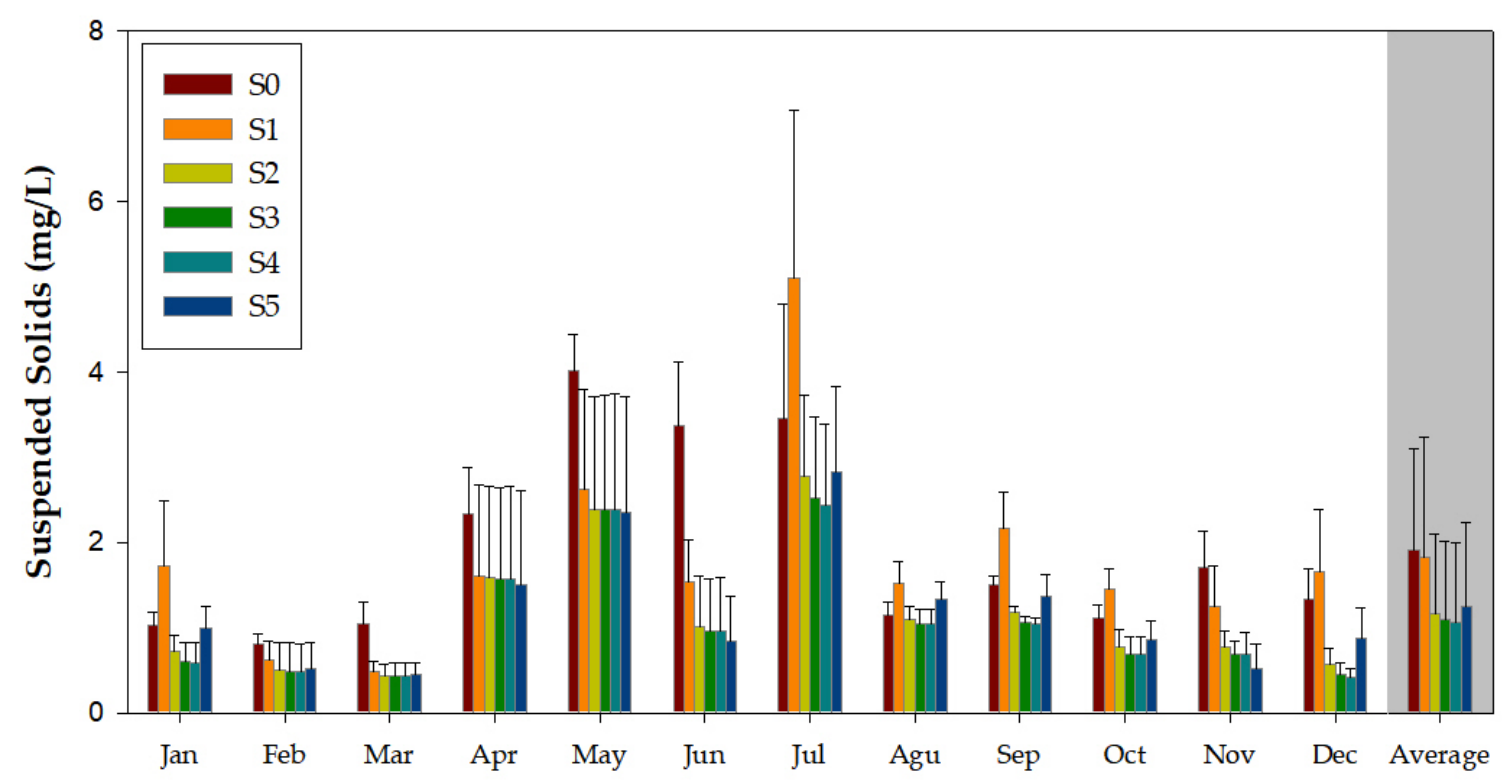

Time (month)

Figure 8. Comparison of changes in the monthly SS concentration at the DG2 site in Kangnung Namdae Stream.

\section{Conclusions}

This study aimed to predict the impact of water management practices such as constructed wetlands on water quality. The HSPF and CE-QUAL-W2 models were used to simulate the upland watershed and water body of Doam Lake, and the EFDC model was applied to the downstream water body, Kangnung Namdae Stream. We developed model scenarios by combining three water management practices: (1) constructed wetlands for river management, (2) artificial floating islands and sedimentation basins for in-lake management, and (3) selective withdrawal. Based on the results of our analysis, the constructed wetlands applied to Kangnung Namdae Stream significantly reduced the SS concentration of the stream by approximately $30 \%$. The in-lake management practices such as artificial floating islands and sedimentation basins in Doam Lake further decreased the SS concentration by approximately $7 \%$. Finally, selective withdrawal created a $\sim 10 \%$ difference in the average SS concentration in the influents flowing into Kangnung Namdae Stream; however, the effluents passing through the constructed wetlands had only a difference of $1.9 \%$. This indicates that the reduction efficiency of the constructed wetlands has a more positive effect on the water quality of the stream than the selective withdrawal has. When considering the efficiency of individual water management practices, our model suggests that the use of constructed wetlands is the most effective practice to reduce SS concentrations.

When compared to the Korean environmental water quality standards of lakes (SS $5 \mathrm{mg} / \mathrm{L}$ ), the water quality is expected to surpass the standard when the discharge is resumed; however, it is also predicted to generally meet the standard when all practices, such as constructed wetlands, in-lake management practices, and selective withdrawal, are applied. Furthermore, the increased flow due to the effluent discharge is expected to contribute to securing the amount of instream flow in Kangnung Namdae Stream. From the analysis of scenarios with the application of several water quality management practices, it is necessary to combine the constructed wetlands, in-lake water quality management practices, and selective withdrawal in order to restart the power generation of Doam Dam. From the results of this research, we can suggest that setting up an appropriate modeling tool is useful to investigate the quantitative effects of water quality management practices, which provides practical guidelines for the application of water quality management policies. 
Author Contributions: H.W.L. and B.-M.Y. performed model simulations and data analysis, and wrote the manuscript; J.H.C. contributed to configuring the text on methods, results, and discussion. All authors have read and agreed to the published version of the manuscript.

Funding: This research was supported by the Basic Science Research Program through the National Research Foundation of Korea (NRF) funded by the Ministry of Education (2018R1A6A1A08025520 and NRF-2018R1D1A1B07049419).

Conflicts of Interest: The authors declare no conflict of interest.

\section{References}

1. Ribaudo, M.O.; Horan, R.D.; Smith, M.E. Economics of Water Quality Protection from Nonpoint Sources: Theory and Practice; Report No. AER-782; U.S. Department of Agriculture: Washington, DC, USA, 1999.

2. Lenzi, M.A.; Di Luzio, M. Surface runoff, soil erosion and water quality modelling in the Alpone watershed using AGNPS integrated with a Geographic Information System. Eur. J. Agron. 1997, 6, 1-14. [CrossRef]

3. Montgomery, D.R. Soil erosion and agricultural sustainability. Proc. Natl. Acad. Sci. USA 2007, 104, 13268-13272. [CrossRef] [PubMed]

4. Lawler, D.M.; Petts, G.E.; Foster, I.D.; Harper, S. Turbidity dynamics during spring storm events in an urban headwater river system: The upper tame, west midlands, UK. Sci. Total Environ. 2006, 360, 109-126. [CrossRef] [PubMed]

5. Akan, A.O.; Houghtalen, R.J. Urban Hydrology, Hydraulics, and Stormwater Quality: Engineering Applications and Computer Modeling; John Wiley \& Sons, Inc.: Hoboken, NJ, USA, 2003.

6. Thorpe, T.; Lloyd, B. The macroinvertebrate fauna of St. Lucia elucidated by canonical correspondence analysis. Hydrobiologia 1999, 400, 195-203. [CrossRef]

7. Lee, H.W.; Kim, E.J.; Park, S.S.; Choi, J.H. Effects of climate change on the movement of turbidity flow in a stratified reservoir. Water Resour. Manag. 2015, 29, 4095-4110. [CrossRef]

8. Lee, S.I.; Shin, J.Y.; Shin, M.H.; Ju, S.H.; Seo, J.Y.; Park, W.J.; Lee, J.Y.; Choi, J.D. Characteristics of non-point pollutant runoff in highland field fields through long-term monitoring. J. Korean Soc. Agric. Eng. 2017, 59, 85-96. [CrossRef]

9. Cho, J.H. Pollutants removal efficiency of rainfall-runoff from dense highland field areas in multistage sedimentation basins-Focused on Jaun area in upstream watershed of Lake Soyang. J. Environ. Impact Assess. 2018, 27, 170-180. [CrossRef]

10. Cooper, P.F.; Job, G.D.; Green, M.B.; Shutes, R.B.E. Reed Beds and Constructed Wetlands for Wastewater Treatment; WRc Publications: Marlow, Bucks, UK, 1996.

11. Jou, C.J.; Chen, S.W.; Kao, C.M.; Lee, C.L. Assessing the efficiency of a constructed wetland using a first-order biokinetic model. Wetlands 2008, 28, 215-219. [CrossRef]

12. Lin, Y.F.; Jing, S.R.; Lee, D.Y.; Chang, Y.F.; Chen, Y.M.; Shih, K.C. Performance of a constructed wetland treating intensive shrimp aquaculture wastewater under high hydraulic loading rate. Environ. Pollut. 2005, 134, 411-421. [CrossRef] [PubMed]

13. Kadlec, R.H. Deterministic and stochastic aspects of constructed wetland performance and design. Water Sci. Technol. 1997, 35, 149-156. [CrossRef]

14. Van Oostrom, A. Nitrogen removal in constructed wetlands treating nitrified meat processing effluent. Water Sci. Technol. 1995, 32, 137-147. [CrossRef]

15. Horne, A.J. Nitrogen removal from waste treatment pond or activated sludge plant effluents with free-surface wetlands. Water Sci. Technol. 1995, 31, 341-351. [CrossRef]

16. Korea Meteorological Administration. Available online: http://www.kma.go.kr/(accessed on 13 March 2019).

17. Yeom, B.M.; Lee, H.W.; Moon, H.I.; Yun, D.G.; Choi, J.H. Study on the management of Doam dam operation by the analysis of suspended solids behavior in the lake. J. Korean Soc. Water Environ. 2019, 35, 470-480. [CrossRef]

18. Bicknell, B.R.; Imhoff, J.C.; Kittle, J.L., Jr.; Jobes, T.H.; Donigian, A.S., Jr.; Johanson, R.C. Hydrological Simulation Program-FORTRAN (HSPF): User's Manual for Version 12; US Environmental Protection Agency: Athens, GA, USA, 2001.

19. Albek, M.; Öğütveren, Ü.B.; Albek, E. Hydrological modeling of seydi suyu watershed (turkey) with HSPF. J. Hydrol. 2004, 285, 260-271. [CrossRef] 
20. Göncü, S.; Albek, E. Modeling climate change effects on streams and reservoirs with HSPF. Water Resour. Manag. 2010, 24, 707-726. [CrossRef]

21. Edinger, J.E.; Buchak, E.M.; Merritt, D.H. Longitudinal-vertical Hydrodynamics and Transport with Chemical Equilibria for Lake Powell and Lake Mead. In Salinity in Watercourses and Reservoirs; French, R.H., Ed.; Butterworth Publishers: Stoneham, MA, USA, 1983; pp. 213-222.

22. Martin, J.L. Application of two-dimensional water quality model. J. Environ. Eng. 1988, 114, $317-336$. [CrossRef]

23. Garvey, E.; Tobiason, J.E.; Hayes, M.; Wolfram, E.; Reckhow, D.A.; Male, J.W. Coliform transport in a pristine reservoir: Modeling and field studies. Water Sci. Technol. 1998, 37, 137-144. [CrossRef]

24. Wu, G.; Xu, Z. Prediction of algal blooming using EFDC model: Case study in the Daoxiang Lake. Ecol. Model. 2011, 222, 1245-1252. [CrossRef]

25. Ministry of Environment (ME). Available online: http://www.me.go.kr/ (accessed on 10 July 2019).

26. Ministry of Environment. Monitoring and Evaluation of Doam Lake Nonpoint Source Management Area (VI); Ministry of Environment: Sejong, Korea, 2014.

27. Korea Hydro \& Nuclear Power Corporation. Methodology Development of Water Quality Estimation and Impact Assessment for Doam Reservoir; Korea Hydro \& Nuclear Power Corporation: Gyeongju-si, Korea, 2018.

28. Korea Rural Community Corporation. Survey and Manual for Water Quality Improvement of Agricultural Reservoir; Korea Rural Community Corporation: Naju-si, Korea, 2009.

29. Weber, M.; Rinke, K.; Hipsey, M.R.; Boehrer, B. Optimizing withdrawal from drinking water reservoirs to reduce downstream temperature pollution and reservoir hypoxia. J. Environ. Manag. 2017, 197, 96-105. [CrossRef]

30. Zouabi-Aloui, B.; Adelana, S.M.; Gueddari, M. Effects of selective withdrawal on hydrodynamics and water quality of a thermally stratified reservoir in the southern side of the Mediterranean Sea: A simulation approach. Environ. Monit. Assess. 2015, 187, 292. [CrossRef]

31. Nikitina, O.I.; Dubinina, V.G.; Bolgov, M.V.; Parilov, M.P.; Parilova, T.A. Environmental Flow Releases for Wetland Biodiversity Conservation in the Amur River Basin. Water 2020, 12, 2812. [CrossRef]

32. Kadykalo, A.N.; Findlay, C.S. The flow regulation services of wetlands. Ecosyst. Serv. 2016, 20, 91-103. [CrossRef]

33. Stefanakis, A.I. The Role of Constructed Wetlands as Green Infrastructure for Sustainable Urban Water Management. Sustainability 2019, 11, 6981. [CrossRef]

34. Wan, Z.; Li, Y.; Wang, X.; An, J.; Dong, B.; Liao, Y. Influence of Unsteady Flow Induced by a Large-Scale Hydropower Station on the Water Level Fluctuation of Multi-Approach Channels: A Case Study of the Three Gorges Project, China. Water 2020, 12, 2922. [CrossRef]

35. Beecher, H.A. Standards for instream flows. Rivers 1990, 1, 97-109.

Publisher's Note: MDPI stays neutral with regard to jurisdictional claims in published maps and institutional affiliations.

(C) 2020 by the authors. Licensee MDPI, Basel, Switzerland. This article is an open access article distributed under the terms and conditions of the Creative Commons Attribution (CC BY) license (http://creativecommons.org/licenses/by/4.0/). 